views, that is, "that conditioned inhibition is initiated in the cortical nerve cells of the focus of the conditioned stimulus", as well as the alternative view, "that conditioned inhibition is initiated in the nerve cells of the focus of the unconditioned stimulus". (He also rejects the view of Kupalov, which combines these two hypotheses.) Asratyan's own theory amounts to saying "that conditioned inhibition is initiated primarily in the elements of the conditioned connexion itself, which we represent as a chain of internuncial neurones". Most of the work he quotes in support comes from experiments on "transswitching" ; this term is used by him to designate an experimental paradigm in which ". . . a single indifferent stimulus is given two different signal values at the same time. This is done by reinforcing the stimulus differently in two different experimental conditions or situations". These experiments are interesting, but scarcely conclusive; Asratyan does not, for example, discuss at all the difficulties which would be presented for his theory by the results of Culler's classical experiment of 1938.

It is noteworthy that, while the American and Russian participants at this Conference do occasionally take notice of each other's work, yet in the main there is no real bridge from one group of workers to the other. This may be a question of nationality and politics; but other possibilities spring to mind. Electro-physiologists in the United States, and in Great Britain too, pay just as little attention to the work, or the contribution, of Western psychologists active in the field of modern learning theory and conditioning as they do to the Russians; the encapsulation of separate disciplines is more likely to be the villain of the piece, rather than national or political prejudices.
H. J. EYSENCK

\title{
THE CHANGING INDUSTRIAL ENVIRONMENT
}

$\mathrm{T}$

HE theme of the annual conference of the Institute of Personnel Management which was held at Harrogate during October 7-9 was "People and Machines".

Various developments in personnel management and industrial relations were considered by the 1,200 individuals who attended from industrial companies, local and central government departments, universities and other higher educational institutions throughout the world. The tone and conduct of the conference were again on such a high plane that it is bound to have far-reaching consequences. Responsibility for organizing a conference which, outside those of political parties and trade unions, is probably the biggest in Great Britain lies mainly with Miss H. E. Cutting, who must be congratulated for the quietly efficient way in which these conferences take place.

The opening address was given by the newly appointed Minister of Labour, the Rt. Hon. John Hare, who, after reviewing the general principles on which the Government acts in the field of industrial relations, described the measure of success which stems from the British system of free negotiation. In the twelve months from June 1959 to June 1960, for example, more than 300 important claims for increased wages or shorter hours covering practically the whole of industry were settled peacefully, while less than ten resulted in disputes which led to strikes.

Strikes can be put broadly into two categories. First, there are strikes over clear-cut economic issues affecting wages or conditions of work. These, if they take place after the procedure of negotiation has been followed and failed to produce agreement, are one of the consequences to be accepted as inevitable from time to time in a free society where those who work have the right and power to seek the conditions of employment they feel that they are entitled to.

The second category contains the large number of strikes in individual establishments over a wide variety of difficulties, not only wages, which arise between management and labour or between different groups of workers. They arise over such issues as discipline, dismissals, redundancy, working arrangements and union membership. The causes of many of them are sometimes obscure-at least to the general public. Most of them are unofficial.

This second category of strike has recently given rise to public criticism. Industry itself, both employers and trade unions, is gravely concerned about them. Mr. Hare indicated that these criticisms and fears are justified because these strikes indicate continuing weakness in the present system. The Minister recommended that the two sides of the motorcar manufacturing industry should set up a top-level study group, or informal committee, to produce constructive proposals for overcoming the problems which cause regrettable stoppages within the industry -wnether these problems arise on the management or the workers' side. The Minister indicated his readiness to help such a group.

At one of the sectional meetings the issue of whether collective bargaining should be carried out nationally or locally was examined. Prof. E. H. Phelps Brown showed how, in the years of full employment sinee the Second World War, there has been a substantial increase in the extent to which actual terms and conditions of employment are regulated by bargaining between firms and their own workpeople. Much of our collective bargaining now has a two-tier structure : from time to time each employee gets a rise the amount of which is fixed by an industrywide bargain, but this actual rate depends also on a bargain struck within the firm. The procedure by which these local agreements are reached vary widely, and many are informal, but, in one way or another, they involve negotiation between a firm's manayement and its own work-people.

Is this development to be welcomed or resisted ? Negotiation firm by firm avoids the danger of industrywide bargaining and that rises in money wages will be granted too readily, because all competitors will have to pay them and so expect to be able to cover them by a general rise in selling prices. On the other hand, there is a danger that the different rates for the same job in different firms will give rise to unrest and whip-sawing.

Mr. G. Moxon, of United Glass, Ltd., was firmly against any proposal to decentralize wage-rate bargaining. Such a proposal presents a major 
change to the established and traditional system affecting all companies in some degres or other, but affecting most markedly multiple companies with factories in different parts of the country.

Moxon's objections to the proposal may be summarized as follows: there is no evidence that the decentralization of wage negotiations would result in more acceptable bargains than is the case under the present system. On the contrary, it is at least possible that disputes would increase and factory relations would become worse if wage-rate bargaining were brought to the factory floor. There is no evidence that the decentralization of negotiations would diminish such tendencies as there are to a wage-price spiral ; decentralized wage-rate bargaining is likely to have the effect of transferring a good deal of responsibility for bargaining away from the senior ranks of trade union officials (for example, national officers), into the hands of less-experienced, and sometimes less-successful, officials at plant-level where shop stewards will exercise a considerable influence; factory bargaining for increases beyond minima would necessitate some unified body of unions to negotiate on a common front with company management. This would mean a unified body embracing craft and general workers' unions. Without this safeguard, management would be exposed to leap-frog tactics by the various unions with which it negotiates.

The education and training of technicians were elaborated by Mr. J. S. Newton of Pilkington Bros., who used sections of the Crowther Report to distinguish between the craftsman, technician and technologist. The former has sufficient skill to make components, the second has enough training and industrial experience to supervise the carrying out of various skills, and the technologist has sufficient training to apply highly complicuted scientific and technological methods to production. The technician has been brought into existence in order to solve a two-fold problem : (a) craftsmen in modern times are being asked to tackle work beyond their scope; (b) highly trained men are being wasted on work requiring much less potential. The technician must have extensive grounding in many skills, and must be intellectually more able than the craftsman. He must supply the 'know-how', and acquire the arts of communication and management. He forms the vital link between the other two grades.

Industry must decide what its requirements are in each grade, and begin by careful selection for each grade, considering educational qualifications along with general background. This may help to decrease the failure-rats between commencing and finishing a college course.

Training given at work must be carefully planned, and watched closely if it is decentralized; trainees should not be used as cheap labour. The training officer must have a clear-cut policy to implement, and planning and reports must be centralized. If training is centralized, it must not be isolated from production. If it is decentralized it must be on a systematic basis, with set periods under different operator/trainers, who must be paid special rates so that their earnings do not suffer. Industrial training must supply the trainee with as wide a field of experience as possible, filling in gaps with short-period visits to other factories, on an exchange system. Trainee technicians must have early experience of dealing with emergencies. Training must be devised to develop and mature their personalities.
The British contribution to the development of personnel management in newly industrializing countries was discussed by two speakers with considerable experience overseas. Mr. F. J. Pedler, of the United Africa Co. Ltd., declared that the golden rule for staff relations is to treat African workers in Africa as one would treat English workers in England. "If one begins by treating an African trade union as one would treat a respectable trade union in England one cannot go very wrong." The assumption is too commonly made that trade unions in Africa are subversive, communist, corrupt and unrepresentative. Some African trade unions are fully responsible. It is true that some are dominated by communists, and others, without being communist, are identified with political parties in their own country. The influence of Israel on trade union structure has been strong in some African countries.

Employers should be bold and sympathetic in recognizing unions and helping them to develop along the right lines. The technique of a joint industrial committee, for example, has been widely used in Africa with success.

The basic fact about African labour is that it is very scarce. It has to be managed as a scarce commodity, as it already commands the price of a scarce commodity : the position in Africa is very different from India.

It is important that political urges and economic development should be brought into harmony and made to serve useful ends. In this problem, personnel management has a big part to play. Such management must handle the basic problem of labour scarcity in such a way that the cost of wages and fringe benefits do not put a brake on investment.

The training of staff at all levels is essential. One of the important things which England can pass on to Africa through good personnel management is the conception of a commercial company as a com. munity of men united for a common purpase : and, within the larger community, the conception of esch unit-whether it be a department or a training school -as a team in which there are corporaie interests. The most important step in achieving such a spirit is to promote Africans to be managers and to associate them fully in running the business.

Mr. John Marsh, Industrial Welfare Society, suggested that, in helping the development of personnel management in countries overseas, the British contribution should insist that our daily practice in industry and commerce should be an example. This is particularly true if the British control or administer expatriate enterprises in foreign lands.

Personnel officers and other managers who serve ahroad for a port on of their lives are especially important as ambassadors of modern Britain. The Govern. ment is making a special effort to ensure that teachers going to the Commonwealth should have safeguards in their future careers, and Civil servants serving in other lands are now more satisfactorily protected. Service in industry and commerce overseas is still a handicap instead of a credit to a man's career. By sharing our knowledge and experience with indigenous managers and specialists sent to the United Kingdom for training and development, Britain makes a considerable contribution to the development of good industrial relations overseas.

The closing address was given by Sir Ben Lockspeiser, of Tube Investments, Ltd., who described the evolution of machines manufactured by man to create 
the environment in which he now lives. But, although man is good at designing machines, he is not so good at understanding human behaviour, and the introduction of electronic machines could have lamentable social consequences if the personal problems involved are neglected. Many people are bound to be affected personally. Considerable changes of technique cannot be brought about overnight. The period of adjustment is long enough to give those in authority the opportunity of using the means at their disposal, such as retraining schemes and the adaptation of recruitment and wastage-rates, to anticipate consequences and work out the necessary human measures to meet new circumstances. Good personnel management must accompany a developing technology.

T. H. HawkINS

\section{EPIDEMIOLOGY OF BLACK RUST OF WHEAT}

A SYMPOSIUM on "Epidemics of Black (Stem) Rust of Wheat" was held in the afternoon of October 7 under the auspices of the British Mycological Society. Mr. L. Ogilvie (National Agricultural Advisory Servico, Bristol) said that the alternate host of black rust, wild barberry, does not appear to be implicated in the origin of uniformly distributed and almost simultaneous epidemics in the southwest of England. It was therefore decided to find whether uredospores are transported from the Continent in the same way as they are carried northwards from Texas into the American wheat belt.

Collaborative investigations which have been proceeding in Western Europe and North Africa since 1958 show that the disease overwinters in the uredospore stage on wheat and grasses in North Africa and Southern Iberia, and spreads northwards in summer. Observations on field crops and on some thirty widely scattered 'rust nurseries' (small plots of varieties of spring wheats) were organized from Bristol. About a fortnight after uredospores were trapped in quantity, rust was found in the fields and from then on became common in most of the southern coastal areas, the Channel Islands and Isles of Scilly and, later, to a lesser degree, in the whole of the southern half of England.

Dr. I. G. Thorpe (National Agricultural Advisory Service, Bristol) stated that the oat, barley, and some grass varieties of Puccinia graminis are not uncommon on barberries in England, but the wheat variety has not been found in recent years. The simultaneous appearance of the disease over a large area suggests a widespread inoculum. Uredospore deposits on spore traps can usually be correlated with air trajectories from countries to the south, as is explained later. Up to the present, the spectrum of rust races recognized in England greatly resembles that of the Iberian Peninsula and France. Mr. H. A. Hyde and Mrs. K. F. Adams (National Museum of Wales, Cardiff) reported that black rust uredospores have been found from May onwards in the spore catches organized by the Asthma and Allergy Research Unit at Cardiff and the Bishop Rock Lighthouse, often before wheat is affected in England. Simultaneous catches of black rust spores have often been made at points more than 150 miles apart. The theory of spore clouds originating from the Continent is supported also by catches in spring of pine pollen, which apparently came from southern Europe.

Mr. W. H. Hogg (Meteorological Office, Bristol) described how air trajectories could be prepared from weather maps, and gave estimates of the errors involved. Uredospore catches in London during the period July 4-10, 1959, were accompanied by air trajectories from the Continent. When the air came from other quarters, spores were few or lacking. Dr. J. M. Hirst (Rothamsted) dealt with theories underlying the liberation, transport and deposition of rust uredospores. Sampling from aircraft traversing southerly airstreams over the English Channel have shown large numbers of spores at heights up to $7,000 \mathrm{ft}$.

Conclusions which may be drawn from the symposium are that a severe black rust epidemic in England depends on susceptible varieties of wheat (all varieties grown here are susceptible to the common West European races of black rust), lateness of the wheat crops, transport of spore clouds arising from epidemics to the south by one or more favourable wind trajectories in late June or early July, and warm and humid weather at the time of infection and for several weeks later.

\section{TROPICAL ECOLOGY}

$\mathrm{E}^{\mathrm{c}}$ COLOGICAL terminology and concepts applicable to, and developed under, temperate conditions sometimes have little relevance to the vegetation of the tropics, and a journal devoted especially to tropical ecology will be welcomed by many as meeting a real need, so long as it does not encourage ecologists in differing climatic zones to overlook the essential unity of their subject.

Nos. 1 and 2 of Vol. 1 of the Bulletin of the Inter national Society for Tropical Ecology give little indication of the extent to which this new journal will, in fact, meet the need which undoubtedly exists. No. 1 contains a presidential address : "Why Tropical Ecology ?" by J. C. Sen Gupta, as well as abstracts of 22 papers, mainly on tropical forests, given at a symposium on forest ecology held at Bombay. In No. 2 are rather longer accounts of 21 papers read at a forest ecosystem symposium which was a part of the ninth International Botanical Congress held at Montreal. There is thus an absence of research papers of the conventional type ; but it is useful to have the views of experts from many countries on forest classification assembled together in a single volume in this way.

No indication is given as to whether succeeding numbers of this journal will be restricted to abstracts of papers read at symposia and conferences, or whether the journal is to restrict itself to tropical 